\title{
KONTROVERSI PELAKSANAAN OTONOMI DAERAH
}

\author{
M. Makhfudz \\ Fakultas Hukum Universitas Tama Jagakarsa \\ Email : muhammadmakhfudz@ymail.com \\ m_makhfudz@yahoo.com
}

\begin{abstract}
Regional Autonomy has been one of the feasible models for the Government to accelerate its development programs to achieve social welfare as it equally distributes shares of workload of the Central Government, correspondingly passing them to local governments and continuously to the smallest authorities. Regional Autonomy should be promoted through mass media in a bid to promote public awareness of and to collect public support for social-economic development, making them aware of their contribution. This paper is based on descriptive research and normative analysis, comparing empirical facts in sampling locations.
\end{abstract}

Keywords : Transparency, Distributions of Workload, Democratic

\begin{abstract}
Abstrak
Pelaksanaan otonomi, sebagai salah satu pilihan sistem yang dapat digunakan oleh pemerintah untuk mempercepat terciptanya kesejahteraan masyarakat. Karena otonomi adalah sebagai usaha membagi rata tanggung jawab pemerintahan pusat. Kemudian beban tanggung jawab dibagi ke pemerintahan lokal, sampai yang paling bawah. Demikianlah juga sebagai media pendidikan politik, yaitu dengan meningkatkan pengertian rakyat serta dukungan mereka dalam kegiatan usaha pembangunan sosial ekonomi, sehingga diharapkan masyarakat bawah dapat merasakan keuntungan dari konstribusi kegiatan usaha mereka. Makalah ini disusun berdasarkan pelaksanaan penelitian yang dilakukan secara deskriptif, dan melakukan analisis normatif dengan membandingkan dengan kenyataan di lapangan yang ditemui pada lokasi penelitian.
\end{abstract}

Kata Kunci : Transparansi, Pembagian Tanggung Jawab, Demokratis

\section{PENDAHULUAN}

\section{Latar Belakang}

Sebagaimana kita ketahui bahwa pelaksanaan otonomi adalah amanat Undang Undang Dasar Negara Republik Indonesia Tahun 1945. Pemerintah daerah berwenang mengatur dan mengurus sendiri urusan pemerintahan menurut asas otonomi dan tugas pembantuan. Pemberian otonomi luas kepada daerah diarahkan untuk mempercepat 
terwujudnya kesejahteraan masyarakat melalui peningkatan pelayanan, pemberdayaan, dan peran serta masyarakat. Disamping itu, melalui otonomi luas daerah dapat diharapkan mampu meningkatkan daya saing dengan memperhatikan prinsip demokrasi, pemerataan, keadilan, keistimewaan dan kekhususan serta potensi dan keanekaragaman daerah dalam sistem Negara Kesatuan Republik Indonesia.

Pemerintah daerah dalam rangka meningkatkan efisiensi dan efektifitas penyelenggaraan otonomi daerah perlu memperhatikan hubungan antar susunan pemerintahan dan antar pemerintahan daerah, potensi, dan keanekaragaman daerah. Aspek hubungan wewenang memperhatikan kekhususan dan keragaman daerah dalam sistem Negara Kesatuan Republik Indonesia. Aspek hubungan keuangan, pelayanan umum, pemanfaatan sumber daya alam dan sumber daya lainnya dilaksanakan secara adil dan selaras. Di samping itu perlu diperhatikan pula peluang dan tantangan dalam persaingan global dengan memanfaatkan perkembangan ilmu pengetahuan dan teknologi. Agar mampu menjalankan perannya tersebut, daerah diberikan kewenangan yang seluas - luasnya disertai dengan pemberian hak dan kewajiban menyelenggarakan otonomi daerah dalam kesatuan sistem penyelenggaraan pemerintahan negara.

Penyelenggaraan desentralisasi mensyaratkan pembagian urusan pemerintahan antara pemerintah dengan daerah otonom. Pembagian urusan pemerintahan tersebut didasarkan pada pemikiran bahwa selalu terdapat berbagai urusan pemerintahan yang sepenuhnya tetap menjadi kewenangan pemerintah. Urusan pemerintahan tersebut menyangkut terjaminnya kelangsungan hidup bangsa dan negara secara keseluruhan. Urusan pemerintahan dimaksud meliputi : politik luar negri dalam arti mengangkat pejabat diplomatik dan menunjuk warga negara untuk duduk dalam jabatan lembaga internasional, menetapkan kebijakan luar negeri, melakukan perjanjian dengan negara lain, menetapkan perdagangan luar negeri, dan sebagainya : pertahanan, 
misalnya mendirikan dan membentuk angkatan bersenjata, menyatakan damai dan perang, menyatakan negara atau sebagian wilayah negara dalam keadaan bahaya, membangun dan mengembangkan sistem pertahanan negara dan persenjataan,; keamanan misalnya mendirikan dan membentuk kepolisian negara, menetapkan kebijakan keamanan nasional, menindak setiap orang yang melanggar hukum negara, menindak kelompok atau organisasi yang kegiatannya mengganggu keamanan negara dan sebagainya; moneter misalnya mencetak uang dan menentukan nilai mata uang, menetapkan kebijakan moneter, mengendalikan peredaran uang dan sebagainya yustisi misalnya mendirikan lembaga peradilan, mengangkat hakim dan jaksa, mendirikan lembaga permasyarakatan, menetapkan kebijakan kehakiman dan keimigrasian, memberikan grasi, amnesti, abolisi, membentuk undang undang, Peraturan Pemerintah pengganti undang undang, Peraturan Pemerintah dan peraturan lain yang berskala nasional.

\section{Permasalahan}

Mencermati uraian di latar belakang tersebut diatas, kemudian dikaji berdasar pelaksanaan di lapangan yang ditemui peneliti tidak sesuai dengan asas otonomi. Otonomi tidak lain adalah penyerahan wewenang yang menjadi urusan pemerintahan pusat diserahkan pada pemerintahan daerah. Penyerahan urusan pemerintahan pusat ke pemerintahan daerah tidak secara keseluruhan, tetapi ada hal - hal yang dikecualikan, karena menyangkut terjaminnya kelangsungan hidup bangsa dan negara secara keseluruhan. Urusan pemerintahan pusat yang dimaksud meliputi : urusan politik luar negeri, pertahanan, keamanan, moneter dan agama serta yustisi. Namun ternyata ada urusan pemerintahan lain yang masih ada, sehingga menurut peneliti tidak sesuai lagi dengan asas otonomi dan prinsip demokrasi. 


\section{Metode penelitian}

Kajian dalam permasalahan ini menggunakan metode penelitian, baik normatif maupun perbandingan dengan pelaksanaan di lapangan. Pendekatan yang dilakukan peneliti dengan menggunakan pendekatan perundang undangan (statue approach) dengan mempertimbangkan teori atau pendapat ahli tentang pelaksanaan otonomi dan latar belakang memilih otonomi dan asas - asas demokrasi yang seharusnya dilaksanakan.

Bahan hukum dalam penelitian in dikumpulkan dengan studi dokumentasi dan pencatatan dengan sistem file, selanjutnya dianalisis dengan model hermeneuties analisys. Artinya, mencoba mencari makna dan merumuskannya dengan cara memberikan interpretasi teks yang menjadi objek untuk ditafsirkan dalam konteks ruang dan waktu.

\section{PEMBAHASAN}

Dalam rangka mengarahkan pelaksanaan pemerintahan ke arah yang disebut kepemerintahan yang baik (good governance). Karakteristik kepemerintahan yang baik (good governance) sebagaimana telah disebutkan pada bagian terdahulu adalah demokrasi, partisipasi, akuntabilitas, transparansi, keterbukaan, berorientasi pada kepentingan rakyat, dan kerangka hukum. Karakteristik good governance tadi tidak bisa diwujudkan manakala peneyelenggara kepemerintahan yang baik tidak memiliki kewenanangan dan tanggung jawab untuk mengurus kepentingan masyarakat sendiri (setempat) menuju prakarsa sendiri berdasarkan aspirasi rakyat setempat, sesuai dengan kondisi, potensi, dan karakteristik yang dimilikinya. Kewenangan dan tanggung jawab dalam membuat keputusan sendiri bukan hanya sekedar membuat keputusan agar rakyat dilibatkan dalam proses peneyelenggaraan pemerintahan, pembangunan, dan pelayanan publik, tapi juga kewenangan dan tanggung jawab dalam membuat sistem dan mekanisme akuntabilitas, bersikap transparan, dan terbuka, dan dalam penegakan hukum. Kewenangan dan 
tanggung jawab untuk membuat keputusan sendiri disebut dengan istilah desentralisasi. Karenanya, membahas good governance tidak bisa melepaskan diri dari masalah desentralisasi.

Kebijakan desentralisasi yang dituangkan dalam UU No. 22 Tahun 1999 yo UU No.32 Tahun 2004 tentang Pemerintahan Daerah diharapkan akan lebih memberi peluang pada perubahan kehidupan pemerintahan daerah yang demokratis untuk mendekatkan pemerintahan dengan rakyatnya, yang pada gilirannya akan meningkatkan kesejahteraan rakyat secara keseluruhan. Hakekatnya demokrasi adalah keterlibatan rakyat (partisipasi) baik dalam penyelenggaraan pemerintahan, pembangunan, dan pelayanan publik, maupun dalam melakukan kontrol atas apa yang sedang dan akan dilakukan pemerintahnya. Rakyat dapat terlibat dan melibatkan diri baik dalam penyelenggaraan pemerintahan pembangunan, dan pelayanan publik, maupun dalam melakukan kontrol efektif terhadap pemerintahnya manakala pemerintah bersikap transparan dan terbuka dalam melaksanakan tugas, fungsi, dan kewenangannya.

Rule of law sebagai salah satu karakteristik good governance lebih mengarah pada keseimbangan kewenangan sesungguhnya juga merupakan ciri dari demokrasi. Masalahnya, apakah kebijakan desentralisasi akan dapat menjamin perkembangan demokrasi di daerah, sehingga good governance dapat diwujudkan?. Karena dalam UU No. 22 Tahun 1999 yo UU No 32 Tahun 2004 dengan tegas menyebutkan bahwa Dewan Perwakilan Rakyat Daerah sebagai lembaga perwakilan rakyat di daerah merupakan 'wahana' untuk melaksanakan 'demokrasi' berdasarkan pancasila.

Persoalan itu yang akan dicoba dicarikan jawabannya pada makalah ini. Dengan demikian, membahas good governance disamping masalah desentralisasi tidak bisa meninggalkan masalah demokrasi. Berkaitan dengan hal ini, maka pada makalah ini juga akan membahas desentralisasi dan demokrasi. 
Mengkaji masalah desentralisasi tidak bisa dilepaskan dengan masalah sentralisasi dalam penyelenggaraan pemerintahan, pembangunan, dan pelayanan publik. Sentralisasi dan desentralisasi di dalam proses penyelenggaraan pemerintahan, pembangunan dan pelayanan publik pada dasarnya berkenaan dengan delegatin of authority and responbility yang dapat diukur dari sejauh mana unit - unit bawahan memiliki wewenang dan tanggung jawab di dalam proses pengambilan keputusan.

Desentralisasi pada dasarnya adalah pelimpahan atau penyerahan kekuasaan atau wewenang di bidang tertentu secara vertikal dari institusi / lembaga / pejabat yang lebih tinggi kepada institusi / lembaga / fungsionaris bawahannya sehingga yang diserahi / dilimpahi kekuasaan wewenang tertentu itu berhak atas nama sendiri dalam urusan tertentu tersebut. $^{1}$

Desentralisasi diartikan pula sebagai suatu sistem, dimana bagian bagian dan tugas negara diserahkan penyelenggaraannya kepada organ yang sedikit banyak mandiri. Organ yang mandiri ini wajib dan berwenang melakukan tugasnya atas inisiatif dan kebijaksanaannya sendiri. Ciri yang penting bagi organ yang didesentralisasikan adalah mempunyai sumber sumber keuangan sendiri untuk membiayai pelaksanaan tugasnya. Desentralisasi adalah pelimpahan wewenang dari pemerintah pusat kepada satuan - satuan organisasi pemerintahan untuk menyelenggarakan segenap kepentingan setempat dari kelompok - kelompok penduduk yang mendiami suatu wilayah. Satuan organisasi itu berikut wilayahnya disebut daerah otonom. Wewenang untuk menyelenggarakan segenap kepentingan setempat berikut kewajiban, tugas, dan tanggung jawabnya tercakup dalam istilah pemerintahan daerah. Desentralisasi diartikan pula sebagai pemerintahan sendiri, atau hak, atau kekuasaan untuk memerintah sendiri. Desentralisasi sebagai pelimpahan kewenangan dalam urusan kemasyarakatan dari pejabat - pejabat politik ke badan - badan

\footnotetext{
${ }^{1}$ Joko Widodo, Good Governance, Penerbit Insan Cendekia, Surabaya 2003, Hal. 39.
} 
pemerintahan yang relatif otonom, atau pemindahan fungsi administratif ke hirarki yang lebih bawah.

Desentralisasi menurut Undang Undang Nomor 5 Tahun 1974, merupakan salah satu dari tiga azaz penyelenggaraan pemerintahan di daerah. Desentralisasi menurut Undang Undang Nomor 5 Tahun 1974 pasal 1 (b) adalah penyerahan urusan pemerintahan dari Pemerintah atau daerah tingkat atasnya kepada daerah menjadi urusan rumah tangganya. Pengertian desentralisasi ini sedikit berbeda dengan pengertian menurut UU No. 22 Tahun 1999 tentang Pemerintahan Daerah. Menurut UU No. 22 Tahun 1999, desentralisasi diartikan dengan penyerahan wewenang pemerintahan oleh Pemerintah kepada Daerah Otonom dalam Kerangka Negara Kesatuan Republik Indonesia. Perbedaanya terletak pada apa yang diserahkan. Menurut UU No. 5 Tahun 1974, yang diserahkan adalah urusan pemerintahan. Sedangkan menurut UU No. 22 Tahun 1999 yang diserahkan adalah wewenang pemerintahan. Pengertian yang terakhir ini sesuai dengan hakekat dari desentralisasi yaitu delegation of authority and responbility sebagaimana telah dikemukakann diatas.

Desentralisasi menurut Bryant dan White dapat bersifat administratif dan politik ${ }^{2}$. Desentralisasi administratif biasanya disebut dekonsentrasi dan berarti delegasi wewenang pelaksanaan kepada tingkat - tingkat lokal. Para pejabat tingkat lokal bekerja dalam batas batas rencana dan sumber - sumber anggaran, namun mereka memiliki elemen kebijaksanaan dan kekuasaan, serta tanggung jawab tertentu dalam hal sifat hakekat jasa dan pelayanan pada tingkat lokal. Diskresi mereka dapat bervariasi, mulai dari peraturan - peraturan pro forma, sampai keputusan yang lebih substansial. Desentralisasi politik atau devolusi berarti wewenang pembuat keputusan dan kontrol tertentu terhadap sumber sumber daya diberikan pada pejabat - pejabat regional dan lokal. Devolusi disebut desentralisasi politik karena yang di desentralisasikan dan 
diserahkan adalah wewenang mengambil keputusan politik dan administrasi.

\section{Faktor - faktor dipilihnya sistem otonomi / desentralisasi}

Pemilihan model penyelenggaraan pemerintahan dan pembangunan apakah sentralisasi atau desentralisasi, keduanya sama sama mempunyai implikasi. Model yang terlalu sentralis tidak sepenuhnya baik, karena pelaksanaan pemerintah dan pembangunan yang sentralistis kurang dapat memperhatikan kebutuhan, permasalahan, dan sumber daya serta karakteristik khusus daerah. Hasilnya pun kurang dapat dinikmati dan menyentuh serta mencerminkan keinginan, kepentingan, dan aspirasi masyarakat kebanyakan. Selain itu, dapat juga memperlemah inisiatif daerah dalam memecahkan masalah yang dihadapinya, efisiensi administrasi akan cenderung menurun seiring dengan meningkatnya tanggung jawab pusat, dan dapat mengurangi kadar demokrasi dalam sistem pemerintahan. Namun model yang tersentralistis, disamping memiliki kelemahan di atas, juga memiliki beberapa kelebihan, yaitu akan dapat menjaga integrasi politik dan pengendalian pembangunan, sangat diperlukan jika kemampuan daerah masih rendah, memudahkan penyaluran dana ke luar negeri, mempercepat proses nation building dan terwujudkannya national unity, dan mempermudah mobilisasi risorsis untuk pembangunan ekonomi dan mengurangi gap dalam pembangunan antar wilayah / propinsi.

Model peneyelenggaraan pemerintahan, pembangunan, dan pelayanan publik yang terlalu desentralistis juga menimbulkan konsekuensi. Masalah itu antara lain ketimpangan dan ketidakseimbangan pertumbuhan sosial ekonomi antar daerah satu dengan yang lainnya. Hal ini karena kondisi masing - masing daerah berbeda. Daerah yang surplus akan lebih besar kemungkinannya lebih maju dan berkembang, sebaliknya yang terjadi dengan daerah minus. Kondisi itu akan berbahaya jika ikatan nasionalisme kurang kuat dan 
akan bisa menimbulkan keresahan sosial dan instabilan politik, yang pada gilirannya akan dapat membahayakan keutuhan dan eksistensi negara yang bersangkutan.

Desentralisasi dipandang dapat mendorong pengambilan keputusan yang lebih cepat dan luwes, atau memberi dukungan konstruktif dalam proses pengambilan keputusan. pengambilan keputusan dalam organisasi ke tingkat yang lebih rendah akan cenderung memperoleh keputusan - keputusan yang lebih baik. Desentralisasi dapat memperbaiki kualitas dan pengambilan keputusan.

Rondinell $^{3}$ menggambarkan secara lebih jelas, mengapa desentralisasi perlu dipilih dalam penyelenggaraan pemerintahan dan pembangunan. Desentralisasi akan dapat meningkatkan efektifitas dalam membuat kebijaksanaan nasional, dengan cara mendelegir tanggung jawab yang lebih besar kepada para pejabat tingkat lokal untuk merancang proyek - proyek pembangunan, agar sesuai dengan kebutuhan dan kondisi setempat. Desentralisasi akan dapat memungkinkan para pejabat setempat untuk dapat lebih mengatasi masalah yang selama ini dianggap kurang baik dan ciri - ciri prosedur yang sangat birokratis di dalam merencanakan dan melaksanakan pembangunan yang sering dialami oleh negara berkembang yang tercipta konsentrasi kekuasaaan, otoritas, dan sumber - sumber yang begitu berlebihan di tingkat pusat. Jika dilihat dari fungsi - fungsi pembangunan yang didensentralisir pada para pejabat, staf pelaksana pada tingkat lokal atau unit - unit administratif yang lebih rendah, akan dapat meningkatkan tingkat pemahaman dan sensitivitas mereka terhadap masalah dan kebutuhan setempat, karena mereka akan bekerja pada tingkat dimana semua permasalahan tersebut terasa paling menekan dan terlihat jelas. Sedangkan bila dilihat dari sisi hubungan kerja, desentralisasi akan dapat lebih mendekatkan, mengakrabkan, dan mengeratkan antara penduduk dengan para pejabat, staf pelaksana, dan 
hal ini memungkinkan mereka mendapat informasi yang lebih baik yang diperlukan dalam proses perumusan rencana pembangunan daripada apa yang dapat mereka peroleh bila hanya menunggu di kantor pusat. Desentralisasi ini dapat meningkatkan dukungan politis dan administratif bagi kebijkasanaan pembangunan nasional pada tingkat lokal, dimana rencana - rencana pembangunan tingkat nasional sering tidak diketahui oleh penduduk setempat. Desentalisasi juga dianggap dapat meningkatkan efisiensi pemerintahan pusat, dengan cara mengurangi beban kerja rutin dan fungsi - fungsi manual yang dapat secara efektif diselesaikan oleh para staf pelaksana lapangan atau para pimpinan unit - unit administratif yang lebih rendah.

Pada kesempatan lain, Rondinell mengemukakan keunggulan desentralisasi, yaitu :

a. Desentralisasi merupakan alat untuk mengurangi kelemahan perencanaan terpusat. Dengan delegasi kepada aparat di tingkat lokal, problema sentralisasi dapat lebih mudah dipecahkan ${ }^{4}$.

b. Desentralisasi merupakan alat yang bisa mengurangi gejala red tape.

c. Dengan desentralisasi, maka kepekaan dan pengetahuan tentang kebutuhan masyarakat lokal dapat ditingkatkan.

d. Dengan desentralisasi, kebijaksanaan pemerintah pusat yang sering tak diketahui dan diabaikan oleh masyarakat dan elit lokal, menjadi lebih dikenal.

e. Dengan desentralisasi, lebih memungkinkan berbagai kelompok kepentingan dan kelompok politik terwakili dalam proses pengambilan keputusan, sehingga mereka mempunyai kesempatan yang sama dalam memperoleh pelayanan pemerintah.

f. Desentralisasi memungkinkan pejabat lokal dapat lebih meningkatkan kapasitas manajerial dan teknisnya. 
Desentralisasi juga merupakan salah satu cara untuk mengembangkan kapasitas lokal. Kekuasaan dan pengaruh cenderung bertumpu pada sumber daya. Jika suatu badan lokal diserahi tanggung jawab dan sumber daya, kemampuannya untuk mengembangkan otoritasnya akan meningkat.

Penulis juga mengutip pendapat Tjokroamidjojo mengemukakan program desentralisasi di Indonesia adalah is an approach to two significant problems; it is method for spreading goverment to all parts of the country, it is a method for accommondating regional differences, regional aspiration and regional demands within the confines of unitary state. Tjokroamidjojo mengemukakan tujuan desentralisasi adalah untuk $^{5}$ :

1) Mengurangi beban pemerintahan pusat dan campur tangan tentang masalah - masalah kecil pada tingkat loal. Demikian pula memberikan peluang untuk koordinasi pelaksanaan pada tingkat lokal.

2) Meningkatkan pengertian rakyat serta dukungan mereka dalam kegiatan usaha pembangunan sosial ekonomi. Demikian pula pada tingkat lokal, dapat merasakan keuntungan dari konstribusi mereka itu.

3) Penyusunan program - program untuk perbaikan sosial ekonomi pada tingkat lokal sehingga dapat lebih realistis.

4) Melatih rakyat untuk bisa mengatur urusannya sendiri (self goverment).

5) Pembinaan kesatuan nasional.

Senada dengan apa yang dikemukakan oleh Sady Sumarjan yang dikutip oleh Nugroho, mengemukakan sistem desentralisasi pemerintahan yang sesuai dengan kondisi geografis dan politis di Indonesia. Penggunaan sistem desentralisasi dimaksudkan :

\footnotetext{
${ }^{5}$ Ibid, Hal. 45
} 
1. Untuk mengurangi beban dan tugas pemerintah pusat. Tugas pemerintah dari suatu negara yang sedang dalam taraf pertama mengadakan pembangunan di segala bidang kegiatan, memerlukan kecakapan dan pengalaman yang melampaui batas kemampuan Pemerintah Pusat, apabila tidak dibantu oleh pemerintah daerah untuk menanggapi kepentingan dan aspirasi masyarakat di daerah. Keadaan ini memerlukan desentralisasi yang bersifat teritorial.

2. Untuk meratakan tanggung jawab. Sesuai dengan sistem demokrasi, maka tanggung jawab pemerintah dapat dipikul rata oleh seluruh masyarakat yang diikutsertakan melalui desentralisasi fungsional dan teritorial, hal mana dapat memperbesar stabilitas pemerintahan pada umumnya.

3. Untuk memobilisasi potensi masyarakat banyak buat kepentingan umum. Melalui desentralisasi diberikan kesempatan kekuatan kekuatan di dalam masyarakat untuk ikut serta mengembangkan diri buat kepentingan umum di dalam daerah mereka masing - masing dan juga buat kepentingan nasional. Dengan demikian dapat pula ditimbulkan persaingan yang sehat untuk membangun tiap - tiap daerah dengan kekuasaan masyarakat di daerah - daerah itu sendiri.

4. Untuk mempertinggi efektifitas dan efisiensi dalam pengurusan kepentingan daerah. Sudah barang tentu masyarakat daerahlah yang lebih mengetahui kepentingan dan spirasi mereka, dan mengurusi kepentingannya secara eektif dan efisien. Di dalam hal ini pemerintah pusat cukup memberikan dorongan, bimbingan, dan bantuan dimana diperlukan.

Beberapa keunggulan dan tujuan densentralisasi sebagaimana disebutkan di atas, menyebabkan banyak negara menyukai desentralisasi sebagai strategi maupun sistem dalam penyelenggaraan pemerintahan, pembangunan, dan pelayanan publik termasuk negara Indonesia. 
Konsekuensi logis dari kebijakan desentralisasi adalah dibentuk daerah otonom. Daerah otonom adalah suatu kesatuan masyarakat hukum yang mempunyai batas wilayah tertentu yang berhak, berwenang, dan kewajiban mengatur dan mengurus rumah tangganya sendiri dalam ikatan Negara Kesatuan Republik Indonesia, sesuai dengan peraturan perundang undangan yang berlaku. Menurut UU No. 22 Tahun 1999, daerah otonom diartikan sebagai kesatuan masyarakat hukum yang mempunyai batas daerah tertentu berwenang mengatur dan mengurus kepentingan masyarakat setempat menurut prakarsa sendiri berdasarkan aspirasi masyarakat dalam ikatan Negara Kesatuan Republik Indonesia. Kewenangan daerah otonom untuk mengatur dan mengurus kepentingan masyarakat setempat menurut prakarsa sendiri berdasarkan aspirasi masyarakat sesuai dengan peraturan perundang undangan disebut dengan otonomi daerah. Daerah otonom berarti daerah yang memiliki otonomi daerah.

Dengan berdasar uraian di atas, maka dikemukakan bahwa daerah otonom memiliki ciri - ciri sebagaimana apa yang dikemukakan oleh Riwu Kaho, antara lain sebagai berikut $:^{6}$

1. Adanya urusan - urusan tertentu yang diserahkan oleh pemerintah pusat atau daerah tingkat atas kepada daerah untuk diatur dan diurusnya dalam batas - batas wilayahnya.

2. Pengaturan dan pengurusan urusn - urusan tersebut dilakukan atas inisiatif sendiri dan didasarkan pada kebijaksanaannya sendiri pula.

3. Adanya alat - alat perlengkapan atau organ - organ atau aparatur sendiri untuk mengatur urusan - urusan tersebut, maka daerah perlu memiliki sumber - sumber pendapatan / keuangan sendiri.

Daerah otonom menurut UU No. 5 Tahun 1974 dibedakan menjadi dua macam tingkatan, yaitu daerah otonom tingkat I dan daerah otonom tingkat II. Daerah otonom menurut UU No. 22 Tahun 1999 tidak 
mengenal tingkatan, namun hanya dikenal dengan istilah daerah propinsi, daerah kabupaten, dan daerah kota. Untuk daerah propinsi berkedudukan juga sebagai wilayah administrasi (lihat pasal 2 ayat (2) UU No. 22 Tahun 1999).

Pelaksanaan desentralisasi diwujudkan dengan pemberian otonomi (hak, wewenang, dan kewajiban untuk mengatur dan mengurus rumah tangganya sesuai dengan peraturan perundangan yang ada) kepada daerah otonom. Sedangkan tujuannya adalah untuk meningkatkan daya guna dan hasil guna penyelenggaraan pemerintahan di daerah, terutama dalam pelaksanaan pembangunan dan pelayanan masyarakat serta untuk meningkatkan pembinaan kestabilan politik dan kesatuan bangsa. Bila dicermati tujuan tadi menurut Riwu Kaho terdapat dua macam aspek (kepentingan), yaitu aspek politik dan aspek administratif. Aspek politik yaitu desentralisasi pemerintahan, dalam arti rakyat dilatih dan diberi kesempatan untuk ikut serta dalam penyelenggaraan pemerintahan melalui unit - unit pemerintahan yang terkecil mulai tingkat desa, daerah tingkat II, daerah tingkat I, dan seterusnya sampai pemerintahan pusat. Aspek teknis administratif adalah untuk memperoleh daya guna dan hasil guna penyelenggaraan pemerintahan dengan titik berat perhatian pada aspek pembangunan dan pelayanan masyarakat.

Menurut UU No. 5 Tahun 1974 tentang pokok - pokok pemerintahan di daerah, pelaksanaan desentralisasi lebih menekankan pada aspek teknis administratif dari aspek politis, yaitu untuk memperoleh daya guna dan hasil guna penyelenggaraan pemerintahan dan pembangunan. Dalam UU No. 5 Tahun 1974 tadi, terdapat perubahan pokok yang cukup mendasar, antara lain sebagai berikut :

1. Prinsip pemberian otonomi yang digunakan bukan lagi seluas luasnya, tapi nyata dan bertanggung jawab.

2. Azaz dekonsentrasi tidak lagi sebagai pelengkap azaz desentralisasi, tetapi dilaksanakan secara bersama - sama. 
3. Pemberian otonomi daerah mengutamakan aspek keserasian disamping aspek pendemokrasian.

4. Pembagian tingkatan daerah otonomi, tidak lagi 3 tingkatan, tetapi 2 tingkatan yaitu daerah tingkat I dan daerah tingkat II.

Implikasi kebijakan desentralisasi (UU No. 22 Tahun 1999) adalah banyak kewenangan yang tadinya menjadi kewenangan daerah propinsi bergeser menjadi kewenangan daerah kabupaten dan kota. Dan Kewenangan daerah propinsi diatur dalam Peraturan Pemerintah Nomor 25 Tahun 2000, tentang kewenangan pemerintah dan daerah propinsi sebagai daerah otonom. Menurut PP No. 25 Tahun 2000 ini urusan yang tidak menjadi kewenangan pemerintah dan daerah propinsi menjadi kewenangan daerah kabupaten dan daerah kota. Kewenangan pemerintah dan daerah propinsi hanyalah merupakan kewenangan yang bersifat strategis saja. Sementara kewenangan yang lebih bersifat teknis operasional menjadi kewenangan daerah kabupaten dan kota.

Bergesernya kewenangan daerah propinsi ke daerah kabupaten dan daerah kota berimplikasi pula pada kewenangan dalam bidang keuangan daerah. Banyak sumber pendapatan daerah yang tadinya menjadi kewenangan daerah kabupaten dan daerah kota. Undang undang No. 18 Tahun 1987 tentang pajak daerah dan retribusi daerah yang telah diganti dengan UU No. 34 Tahun 2000, telah membatasi kewenagan daerah propinsi dalam bidang pendapatan daerah. Demikian pula UU No. 25 Tahun 1999 tentang perimbangan keuangan antara pemerintah pusat dan daerah juga membatasi kewenangan daerah propinsi dalam bidang keuangan daerah. Perimbangan keuangan dari setiap sumber pendapatan antara daerah propinsi dengan daerah kabupaten dan daerah kota senantiasa lebih besar daerah kabupaten dan daerah kota. Sehingga kewenangan keuangan daerah propinsi nyaris tinggal sedikit. 


\section{Alasan kepentingan pelaksanaan pelayanan dasar urusan pemerintah pusat tidak diserahkan daerah.}

Pengertian urusan pemerintah yang bersifat concurent artinya urusan pemerintahan yang penanganannya dalam bagian atau bidang tertentu dapat dilaksanakan bersama antara pemerintah dan pemerintah daerah. Dengan demikian setiap urusan yang bersifat concurrent senantiasa ada bagian urusan yang menjadi kewenangan pemerintah, ada bagian urusan yang diserahkan kepada provinsi, dan ada bagian urusan yang diserahkan kepada kabupaten kota ${ }^{7}$.

Untuk mewujudkan pembagian kewenangan yang concurrent secara proposional antara pemerintah, daerah provinsi, daerah kabupaten, dan kota, maka disusunlah kriteria yang meliputi eksternalitas, akuntabilitas, dan efisiensi dengan mempertimbangkan keserasian hubungan pengelolaan urusan pemerintahan antar tingkat pemerintah.

Urusan yang menjadi kewenangan daerah, meliputi urusan wajib dan urusan pilihan. Urusan pemerintahan wajib,seperti dalam penjelasan adalah suatu urusan pemerintahan yang berkaitan dengan pelayanan dasar seperti pendidikan dasar, kesehatan, pemenuhan kebutuhan hidup minimal, prasarana lingkungan dasar. Sedangkan urusan pemerintahan yang bersifat pilihan terkait erat dengan potensi unggulan dan kekhasan daerah.

Kriteria eksternalitas adalah pendekatan dalam pembagian urusan pemerintahan dengan mempertimbangkan dampak/akibat yang ditimbulkan dalam penyelenggaraan urusan pemerintahan tersebut. Apabila dampak yang ditimbulkan bersifat lokal, maka urusan pemerintahan tersebut menjadi kewenangan kabupaten/kota, apabila regional menjadi wewenang propinsi, dan apabila nasional menjadi kewenangan pemerintah.

\footnotetext{
${ }^{7}$ UU No. 32 Tahun 2004, tentang Pemerintahan Daerah. Penerbit Forum Indonesia Maju. Jakarta 2004. Hal 141
} 
Kriteria akuntabilitas adalah pendekatan dalam pembagian urusan pemerintahan dengan pertimbangan bahwa tingkat pemerintahan yang menangani sesuatu bagian urusan adalah tingkat pemerintahan yang lebih langsung/dekat dengan dampak/akibat dari urusan yang ditangani tersebut. Dengan demikian akuntabilitas penyelenggaraan bagian urusan pemerintahan tersebut kepada masyarakat akan lebih terjamin.

Kriteria efisiensi adalah pendekatan dalam pembagian urusan pemerintahan dengan mempertimbangkan tersedianya sumber daya (personil, dana, dan peralatan) untuk mendapatkan ketepatan, kepastian, dan kecepatan hasil yang harus dicapai dalam penyelenggaraan bagian urusan. Artinya apabila suatu bagian urusan dalam penanganannya dipastikan akan lebih berdaya guna dan berhasil guna dilaksanakan oleh daerah provinsi dan atau daerah kabupaten atau kota dibanding apabila ditangani oleh pemerintah, maka bagian urusan tersebut diserahkan kepada daerah provinsi dan atau daerah kabupaten kota. Sebaliknya apabila suatu bagian urusan akan lebih berdaya guna dan berhasil guna dilaksanakan oleh pemerintah, maka bagian urusan tersebut tetap ditangani oleh pemerintah. Untuk itu, pembagian urusan harus disesuaikan dengan memperhatikan ruang lingkup wilayah beroperasinya bagian urusan pemerintahan tersebur. Ukuran daya guna dan hasil guna tersebut dilihat dari besarnya manfaat yang dirasakan oleh masyarakat dan besar kecilnya resiko yang harus dihadapi.

Sedangkan yang dimaksud dengan keserasian hubungan, yakni bahwa pengelolaan bagian urusan pemerintah yang dikerjakan oleh tingkat pemerintahan yang berbeda, bersifat saling berhubungan.

Dengan mendasarkan urusan pemerintah yang bersifat concurrent, maka ada beberapa bagian dari penyelenggaraan pemerintah di bidang kesehatan tetap mempertahankan dilakukan oleh pemerintah pusat. Hal inilah yang menurut peneliti disebut sebagai faktor keengganan pemerintah pusat untuk menyerahkan ke daerah. Padahal, menurut peneliti, ada urusan yang masuk kategori concurrent, seperti 
pendidikan, sudah diserahkan menjadi urusan daerah. Mulai dari perangkat birokrasi yang tadinya ada, instalasi vertikal (kantor wilayah pendidikan) sudah dilebur menjadi aparat daerah. Bahkan daerah dalam pelaksanaan urusan pendidikan diberi keleluasaan yang lebih, seperti daerah diberi kebebasan untuk menambahkan dalam kurikulum pendidikan. Contoh memasukkan pelajaran bahasa jawa, sunda, dalam kurikulum pendidikan. Berbeda dengan urusan kesehatan khususnya masalah pengawasan obat dan makanan. Seiring dengan dicanangkannya pelaksanaan otonomi daerah tahun 2000, lembaga yang memiliki fungsi mengawasi obat dan makanan masih merupakan bagian dari departemen kesehatan, yang disebut Direktorat Jendral Pengawasan Obat dan Makanan Ditjen POM. Ditjen POM ditetapkan melalui keputusan Presiden Nomor 166 Tahun 2000.

Namun demikian, setelah dicanangkan pelaksanaan otonomi daerah, justru Ditjen POM yang semula masih dibawah Departemen Kesehatan, kemudian melalui Keputusan Presiden Nomor 103 Tahun 2002 dirubah menjadi sebuah lembaga non departemen yang bertanggung jawab langsung pada Presiden. Lembaga tersebut kemudian disebut BPOM ( Badan Pengawasan Obat dan Makanan). Kemudian Menteri Kesehatan membuat usulan pada pemerintah tentang pembagian urusan Pemerintah Pusat dan Daerah (Provinsi, Kabupaten, Kota) di bidang kesehatan yang kemudian ditetapkan dalam Peraturan Pemerintah Nomor 38 Tahun 2007 tentang pembagian urusan pemerintahan, antara pemerintah, provinsi, kabupaten, kota, agar dalam pelaksanaan dilapangan tugas BPOM tidak berbenturan dengan Dinas Kesehatan yang merupakan instansi daerah, sehingga ada bagian bagian urusan kesehatan yang menjadi urusan pemerintah daerah yang dilaksanakan oleh Dinas Kesehatan, baik tingkat propinsi maupun kabupaten dan kota.

Dalam rangka pelaksanaan pada masyarakat daerah BPOM melalui keputusan Kepala BPOM Nomor 0518/SK/KBPOM/2011 tentang 
Organisasi dan Tata Kerja Unit Pelaksana Tugas disingkat UPT, membentuk BPOM di setiap Ibu Kota Propinsi.

Berdasar temuan di daerah pelaksanaan PP No. 38 Tahun 2007, peneliti temukan adanya pelimpahan wewenang sehingga kondisi ini berarti tidak ada pembagian tanggung jawab sebagai konsekuensi pelaksanaan sistem demokrasi sebagaimana diurai diatas.

Dengan demikian, telah terjadi adanya pelaksanaan birokrasi yang tidak efektif dan efisien, sebagaimana dikemukakan oleh Yusuf Hariri, S.H, M.Si berpendapat, seharusnya setelah otonomi daerah dilaksanakan harus terjadi perubahan mindset dan cultural set dari pejabat administrasi pemerintahan. Perubahannya menjadi mendasar karena selama ini kenyataan yang sering dirasakan oleh masyarakat, birokrasi masih belum efektif, efisien dan produktif serta dalam menjalankan fungsi dan tugasnya melayani masyarakat masih mendahulukan kekuasaan, dibanding dengan pengabdian ${ }^{8}$.

Penulis menyimpulkan kondisi keengganan pemerintah menyerahkan urusan pemerintahan ke daerah adalah mencerminkan kuatnya birokrasi. Hal ini bisa diambil dalam bahasa sehari - hari istilah birokrasi menjadi satu julukan yang mengacu pada infisiensi dan inefektivitas pemerintahan. ${ }^{9}$ Demikian juga Gruber menggambarkan birokrat sulit dikontrol dengan mengatakan the bureaucrat not only describe themselves as being relatively free from such control, they also do not perceive much of a need for it. Birokrat menggambarkan dirinya sebagai sosok yang terbebas dari setiap kontrol, mereka juga menganggap bahwa dirinya tidak memperlukan kontrol.

Namun sebetulnya pengertian birokrasi tidak seperti tersebut diatas, tapi dalam banyak hal birokrasi dapat bermanfaat untuk mencapai apa yang diinginkan masyarakat, yaitu kesejahteraan. Karena pengertian birokrasi adalah merupakan suatu lembaga yang sangat kuat dengan

\footnotetext{
${ }^{8}$ Majalah Pelayanan Publik, ISSN 0216 - 8480, Vol. I, No. 9, Sept 2005 Hal. 19

${ }^{9}$ Peter M. Blait, Marshall W. Meyer, Birokrasi Dalam Masyarakat Modern, Penerbit Prestasi Pustaka Raya, Jakarta 2000, Hal. 3
} 
kemampuan untuk meningkatkan kapasitas - kapasitas potensial terhadap hal - hal yang baik maupun buruk, karena birokrasi merupakan instrumen administrasi rasional yang netral pada skala besar.

Birokrasi mempermudah ekspansi imperialistis dan eksploitasi ekonomi sehingga dapat merusak bangsa - bangsa yang terbelakang dan orang - orang miskin. Tetapi mekanisme administrasi dalam skala besar ini juga diperlukan dalam masyarakat - masyarakat modern yang kompleks untuk mencapai sasaran - sasaran demokratik dengan harapan bisa meningkatkan standar kehidupan masyarakat, mendistribusikan penghasilan secara lebih merata atau meningkatkan pengaruh warga negara terhadap pemerintah mereka. Menghilangkan birokrasi berarti meniadakan harapan - harapan bagi realisasi sasaran sasaran ini. Persoalan - persoalan yang dihadapi oleh masyarakat modern adalah bagaimana meraih dan mempertahankan kontrol yang demokratis terhadap birokrasi - birokrasi, sehingga mereka bisa berfungsi demi kepentingan dan kesejahteraan bersama. ${ }^{10}$ Maka dengan demikian jika gagasan - gagasan baru yang ingin menemukan ungkapannya dalam perubahan kelembagaan, mereka harus diimplementasikan secara birokratis. Dengan demikian, semua komponen bangsa ini harus ikut mendukung pelaksanaan otonomi sebagai pilihan terbaik untuk menuju perubahan yang lebih baik.

Program otonomi daerah yang ada saat ini sesungguhnya memiliki capaian ekonomi yang tinggi. Terbukti paket UU otonomi daerah adalah berkaitan dengan tata pemerintahan dan perimbangan keuangan sehingga mau tidak mau program otonomi daerah sebenarnya harus memiliki dampak yang korelatif dengan adanya peningkatan ekonomi rakyat. Pembangunan dan produktivitas massal harus makin didekatkan pada masyarakat terbawah. Dengan demikian, laju perekonomian nasional harus betul - betul dirasakan dan dimiliki oleh masyarakat

\footnotetext{
${ }^{10}$ Ibid, Hal 5
} 
yang paling bawah. Sehingga jelas bahwa ketika terjadi adanya high cost economy pada masyarakat daerah adalah sebuah kesalahan besar yang berangkat dari ketidakmengertian sama sekali atas filosofi capaian ekonomis dari desentralisasi itu sendiri.

Hal ini dikemukakan oleh Abdul Wahab pada bukunya yang menggambarkan bagaimana sesungguhnya otonomi daerah ingin menepis adanya pepatah yang mengatakan bagai ayam mati di lumbung padi, dimana pada masa sentralistik terjadi penghisapan yang luar biasa dahsyat atas kekayaan - kekayaan daeah oleh pemerintah pusat dan beberapa perusahaan multinasional. Dikatakan bahwa dengan adanya otonomi daerah akan terjadi pemangkasan jalur distribusi keuangan yang semula teramat tinggi di pusat kekuasaan akan disebar ke daerah daerah asal sumberdaya tersebut dikelola. ${ }^{11}$

Ini membuat kemandirian menjadi sebuah ikon bagi perjuangan ekonomis dari otonomi daerah. Hal ini terutama dipicu oleh keharusan dari setiap daerah untuk dapat membiayai anggaran belanja daerahnya masing - masing, seperti dapat kita lihat dalam pasal 79 UU No. 25 / 1999 yang menyebutkan bahwa sumber pendapatan daerah terdiri atas : (1) Pendapatan asli daerah atau PAD. (terdiri dari hasil pajak daerah, hasil retribusi daerah, hasil perusahaan milik daerah, dan hasil pengelolaan kekayaan daerah yang dipisahkan, (2) Dana perimbangan ( jabarannya dapat dilihat pada PP No. 104/2000 ), (3) Pinjaman daerah (jabarannya dapat dilihat pada PP No. 107/2000), (4) Lain - lain pendapatan daerah yang dianggap sah. ${ }^{12}$

Dari penjelasan diatas jelas terlihat bahwa ketergantungan terhadap pusat hanya satu dari empat poin sumber keuangan daerah. Selanjutnya tentang dana perimbangan itu kita dapat melihat pada pasal 80 UU No. 25 / 1999 yang menyebutkan :

\footnotetext{
${ }^{11}$ Solichin. Awahab, Fadillah Putra, Masa Depan Otonomi Daerah, Penerbit SIC 2002, Surabaya 2002, hal. 74

${ }^{12}$ UU No. 32 Tahun 2004, Tentang Pemerintahan Daerah dan UU No. 33 Tahun 2004, Tentang Perimbangan Keuangan, Penerbit Forum Indonesia Maju, Jakarta 2004
} 
1. Dana perimbangan (sejalan dengan pasal 6 UU 25/99 dan jabarannya pada PP No. 104/2000) terdiri dari : (a) Dana bagi Hasil (DBH), yakni dari hasil PBB, Bea Perolehan Hak Atas Tanah dan Bangunan (BPHTB), dan Penerimaan dari Sumber Daya Alam (PSDA), (b) Dana Alokasi Umum (DAU), dana yang dialokasikan dari APBN dengan tujuan pemerataan kemampuan keuangan antardaerah untuk membiayai kebutuhan pengeluarannya dalam rangka pelaksanaan desentralisasi yang besarnya ditentukan dengan memperhatikan potensi daerah, luas daerah, keadaan geografi, jumlah penduduk, dan tingkat pendapatan, dan (c) Dana Alokasi Khusus (DAK), yakni dana yang dialokasikan dari APBN kepada daerah untuk membantu membiayai kebutuhan tertentu sesuai dengan tujuan pokok dana perimbangan, yaitu untuk dapat lebih memberdayakan dan meningkatkan kemampuan perekonomian daerah serta menciptakan sistem pembiayaan daerah yang adil.

2. Bagian daerah dari penerimaan PBB sektor pedesaan, perkotaan, dan perkebunan, serta perolehan hak atas tanah dan bangunan diterima langsung dari daerah penghasil.

3. Bagian daerah dari penerimaan $\mathrm{PBB}$ sektor pertambangan serta kehutanan dan penerimaan dari sumber daya alam, diterima daerah penghasil dan daerah lainnya untuk pemerataan sesuai UU.

Dari sekilas penjabaran normatif di atas, kita dapat menyaksikan bagaimana sesungguhnya paket program otonomi daerah memang diarahkan pada pemberdayaan ekonomi daerah. Hanya saja memang dengan tidak utuhnya konsepsi desentralisasi yang ada pada UU No. 22 / 1999 maupun UU No. 25 / 1999, maka hal itu membawa pada high cost economy dalam kehidupan masyarakat. Padahal sesungguhnya hal ini dapat dijadikan dasar motivasi bagaimana agar pemerintah daerah dapat merangsang kreativitas masyarakat dan dirinya sendiri untuk meningkatkan produktivitas kerjanya, misalkan seperti yang pernah 
dilakukan pemerintah Thailand yang menerapkan sistem kontrol harga produk pertanian dengan mekanisme stocking atau penyimpanan produk pertanian di sebuah gudang dengan sistem pengawetan yang bagus sehingga dapat mengontrol harga ketika terjadi booming.

Masyarakat sendiri kemudian menjadi agen - agen produksi yang aktif karena dirangsang untuk meningkatkan produktivitasnya dan sikap konsumerisme yang berlebihan dari masyarakat akan sedikit demi sedikit terkurangi karena mereka dituntut untuk berproduksi dan lebih dari itu mereka memang diberi ruang yang luas oleh otonomi daerah untuk melakukan hal tersebut.

Hal ini akan terjadi jika desentralisasi dimaknai sebagai pembuka ruang partisipasi dan emansipasi serta berorientasi pada paradigma pemberdayaan yang memang menempatkan masyarakat terbawah sebagai basis material.

Seperti telah di uraikan pada diatas, bahwa desentralisasi politik merupakan suatu rancangan dimana terdapat hubungan yang saling menguntungkan antara pemerintah lokal dan pemerintah pusat. Pemerintah lokal memiliki kemampuan untuk saling berinteraksi dengan unit - unit yang lain dalam sistem pemerintahan yang merupakan bagiannya. Desentralisasi politik juga merupakan cara untuk lebih mendekatkan pembangunan pada rakyat yang lebih mengetahui situasi dan kebutuhan mereka sendiri.

Dengan cara ini sesungguhnya desentralisasi akan menemukan relevansi yang sangat akurat dengan ide pemberdayaan ekonomi daerah yang jauh dari disintegrasi. Selama ini yang ditakutkan adalah dengan adanya desentralisasi fiskal dan peningkatan keberdayaan ekonomi di daerah akan selalu diikuti dengan kecemasan banyak orang daerah akan memisahkan diri sebab mereka merasa telah dapat memenuhi kebutuhan mereka sendiri. Sehingga barangkali muncul pemikiran dari daerah - daerah, “ mengapa kami harus menjadi bagian dari Indonesia, kalau kami sudah dapat memenuhi kebutuhan kami sendiri?". 
Dengan pemberdayaan ekonomi yang dibingkai oleh desentralisasi, maka yang ingin dicapai sesungguhnya adalah pelepasan dependensi untuk menuju interdependensi, misalnya di daerah Riau memiliki potensi yang luar biasa besar di sektor pertambangan minyak, maka jadikanlah Riau sebagai sentral perminyakan di Indonesia dan kembangkan di Riau segala aspek perminyakan. Mulai dari aspek pengembangan instrumentalnya sampai sektor pendidikannya. Di Sulawesi yang berpotensi besar di sektor perikanan pun demikian, beri keleluasaan dan fasilitas lebih bagi Sulawesi untuk mengeksplorasi sebesar - besarnya segala aspek yang berkaitan dengan sektor perikanan. Demikian pula daerah - daerah lainnya dengan ragam potensi yang mereka miliki. Dengan demikian, maka masing - masing daerah akan tergantung untuk memenuhi kebutuhannya dengan daerah - daerah lain sehingga pada titik inilah pemerintah pusat memiliki peran yang sangat penting dan sangat dibutuhkan oleh daerah - daerah. Riau yang memiliki minyak berlimpah tentu membutuhkan beras dari Jawa Barat misalnya, Sulawesi yang memiliki ikan yang banyak tentu membutuhkan alat - alat transportasi laut dari Jawa Timur, dan sebagainya. Inilah konsep pemberdayaan ekonomi daerah yang hanya akan menemukan habitatnya di dalam terbumikannya konsep devolusi seperti tersebut diatas.

Dengan demikian, paradigma pemberdayaan yang berbasis pada masyarakat akan menemukan derajat relevansi yang tinggi ketika bersentuhan dengan makna dari devolusi tersebut, artinya ketika kita menyepakati bahwa paradigma pembangunan dan pemberdayaan yang baik untuk diterapkan adalah bentuk - bentuk pemberdayaan yang berbasis pada masyarakat, maka sesungguhnya hal itu akan menemukan habitat terbaiknya pada wilayah dimana desentralisasi politik disitu menjadi atmosfer. 
Berangkat dari hal tersebut, kita mengenal ada lima paradigma pembangunan yang mendasari proses pelaksanaan pembangunan dalam suatu negara, yaitu :

1. Pertumbuhan, yang menekankan pada trickle down effect dan teori pertumbuhan

2. Welfare state, yang menekankan pada redistribution with growth/basic need

3. No ekonomi, yang menekankan pada ekonomi yang mementingkan rakyat kecil

4. Structuralize yang menekankan pada kondisi keterbelakangan yang disebabkan struktur ekonomi

5. Humanizing yang menekankan pada wawasan manusia ${ }^{13}$

Ada dua pandangan dalam konteks pembangunan berwawasan manusia, yaitu pertama, production centered development yang lebih menempatkan manusia sebagai instrument atau objek dalam pembangunan. Dalam hal ini, lebih berorientasi kepada produktifitas dimana kemakmuran yang melimpah yang menjadikan si miskin menerima secara pasif atau manusia dipandang sebagai factor produksi saja dan mengabaikan manusia lainnya. Kedua, people centered development/human centered development yang menekankan pentingnya kemampuan manusia, yaitu kemampuan manusia untuk mengaktualisasikan segala potensinya sebagai manusia.

Ternyata people centered development menjangkau dimensi yang lebih luas dari sekedar membentuk manusia professional dan terampil yang sesuai dengan kebutuhan untuk dapat memberikan konstribusinya di dalam proses pembangunan. Manusia diletakkan sebagai inti dalam pembangunan sehingga pembangunan harus berasal dari manusia, dilakukan oleh manusia, dan untuk kepentingan manusia. Dengan demikian, pendekatan ini menempatkan manusia sebagai subjek

\footnotetext{
${ }^{13}$ Opcit, Hal. 79
} 
pembangunan dan upaya pemecahan masalah - masalah pembangunan mengenai pemberdayaan.

Sedang tujuannya adalah perkembangan manusia dalam arti aktualisasi yang optimal dari potensi manusia. Paradigm ini member peran kepada individu, bukan hanya sebagai subjek, tetapi sebagai objek yang menentukan tujuan, menguasai sumberdaya, dan mengarahkan proses yang menentukan hidupnya. Oleh karena itu, paradigma ini memberikan tempat yang paling penting bagi prakarsa dan keanekaragaman local serta pentingnya masyarakat local yang mandiri. $^{14}$

Dalam pandangan Budiman, paradigm ini diterjemahkan sebagai upaya pembangunan yang ditujukan kepada manusia melalui penciptaan kondisi atau lingkungan, baik lingkungan politik maupun lingkungan budaya yang dapat mendorong lahirnya manusia kreatif sebab hanya manusia kreatif yang mampu menyelenggarakan pembangunan dan memecahkan masalah yang dimilikinya. ${ }^{15}$

Dalam konsep pemberdayaan mencakup pengertian pembangunan masyarakat dan pembangunan yang bertumpu pada masyarakat. ${ }^{16}$ Pembangunan masyarakat adalah suatu proses yang menyangkut usaha, diantaranya :

1. Usaha masyarakat dan pihak lain untuk meningkatkan kondisi social, ekonomi, dan budayanya

2. Usaha untuk meningkatkan integritas masyarakat ke dalam suatu pola dan tatanan kehidupan yang lebih baik

3. Mengembangkan dan meningkatkan kemandirian dan kepedulian masyarakat dalam memahami masalah dan mengatasi masalah di kehidupannya

\footnotetext{
${ }^{14}$ Ibid, Hal. 80

${ }^{15}$ Ibid, Hal. 81

${ }^{16}$ Ibid, Hal. 81
} 
Namun sangat disayangkan pilihan melaksanakan otonomi yang memeberi harapan pada rakyat di daerah dilandaskna oleh para pimpinan daerah sendiri. Karena dari sejumlah 350 bupati/walikota seluruh Indonesia, sebagian bupati/walikota tidak bisa bertanggung jawab. Tujuan pelaksanaan otonomi itu dilanggar. Terbukti sejumlah 173 bupati/walikota bermasalah dengan hukum. ${ }^{17}$ Dan sejumlah pimpinan daerah seluru Indonesia belum mencapai sasaran $10 \%$ yang diharapkan rakyat, yaitu mensejahterakan rakyat dan memberikan perlindungan pada konsumen.

\section{PENUTUP}

Pelaksanaan otonomi harus dilaksanakan sesuai dengan konsep otonomi yang dimaknai sebagai penyerahan urusan pemerintah pusat ke daerah, kecuali lima kekuasaan yang dipergunakan untuk kelangsungan kehidupan bangsa. Namun diluar lima kekuasaan yang dikecualikan harus diserahkan pada daerah. Dengan mempertimbangkan penyerahan urusan itu sebagai usaha untuk mengurangi beban dan tuga pemerintah pusat. Disamping itu juga, dalam rangka meratakan tanggung jawab. Sesuai dengan sistem demokrasi, maka tanggung jawab pemerintah dapat dipikul rata oleh seluruh masyarakat yang diikutsertakan melalui disentralisasi fungsional dan teritorial. Hal ini dapat menciptakan stabilitas pemerintahan pada umumnya.

Pelaksanaan otonomi juga dapat mempertinggi efektifitas dan efisiensi dalam kepengurusan kepentingan daerah yang sudah barang tentu masyarakat daerahlah yang lebih mengetahui kepentingan dan aspirasi mereka. Pemerintah pusat hanya berperan sebagai motivator, bimbingan dan bantuan dimana diperlukan.

Saran, bagaimana agar pelaksanaan otonomi seyogyanya dievaluasi, terutama hal-hal yang menyebabkan pelaksanaan pemerintahan tidak efektif dan efisien.Seperti penempatan aparat pusat didaerah hanya

\footnotetext{
${ }^{17}$ Media Indonesia, April 2012
} 
berfungsi sebagai pemantau,pembimbing saja.Sehingga penempatan aparat pusat tak usah memiliki perangkat yang melibatkan aparat yang banyak tapi mungkin cukup satu unit organisasi yang bertugas mengawasi / pengawas saja.

\section{DAFTAR PUSTAKA}

Asshiddiqie, Prof, Dr, Jimly, Dimensi Konseptual dan Prosedural Pemajuan Hak Asasi Manusia Dewasa Ini, Perkembangan Kearah Pengertian Hak Asasi Manusia Generasi Keempat, Jakarta, 2000.

Abdulwahab, Prof, Dr. Solichin, Masa Depan Otonomi Daerah, Penerbit SIC Surabaya, 2002.

Bakatullah, S.Ag, S.H, M.Hum, dr. Abdul, Hukum Perlindungan Konsumen, Jakarta, Nusa Media, 2008.

Hartono, Sri Rejeki, Kapita Selekta Hukum Ekonomi, Bandung.

Hartono, Prof Dr Sunaryati, Beberapa Pemikiran Mengenai Peradilan Administrasi Negara Indonesia, Jakarta, Bina Cipta, 1999.

Hadi, prof Sutrisno, Metodologi Research, Yogyakata, Yama Press, 2004.

Joko Widodo Dr, Good Governance, Insan Cendekia, Surabaya, 2004.

Indriyanti Dewi S.H, M.Hum, Alexandra, Mafia Kesehatan, Pinus Yogyakarta, 2008.

Harian, Media Indonesia, Juli, 2012.

Majalah Pelayanan Publik, 2005.

Harian, Mass Media, Sinar Harapan, 2000.

Peter, M Blau, Birokrasi Dalam Masyarakat Modern, Prestasi Pustakaraya, 2000.

UU No. 32 Tahun 2004 tentang Pemerintahan Daerah.

UU No. 33 Tahun 2004 Tentang Perimbangan Keuangan, Penerbit Forum Indonesia Maju, 2004.

Warta POM Vol X Edisi Mei - Juni 2011. 